Indonesian Journal of Biotechnology, December, 2014

Vol. 19, No. 2, pp.129-135

\title{
Evaluation of different promoters driving the GFP reporter gene in seaweed Kappaphycus alvarezii
}

\author{
Muh. Alias L. Rajamuddin ${ }^{1) *}$, Alimuddinn'), Utut Widyastuti³), Irvan Faizal ${ }^{4)}$ \\ ${ }^{1)}$ Postgraduated student of Bogor Agricultural University, Bogor. Polytechnic Agricultural of Pangkep, \\ South Sulawesi. \\ ${ }^{2)}$ Department of Aquaculture, Faculty of Fisheries and Marine Sciences, Bogor Agricultural University, \\ Bogor. \\ ${ }^{3}$ Department of Biology, Faculty of Mathematics and Natural Sciences, Bogor Agricultural University, \\ Bogor. \\ ${ }^{4)}$ Agency for Research Assessment and Application of Technology (BPPT), Serpong.
}

\begin{abstract}
Promoter regulates expression level of foreign gene in transgenic organism. This study was performed to select a suitable promoter as the first step towards production of valuable trait-enhanced seaweed by transgenic technology. Green fluorescent protein (GFP) gene was used as a reporter to determine the activity of promoter in seaweed Kappaphycus alvarezii. GFP gene constructs driven by cytomegalovirus (pCMV-GFP), cauliflower mosaic virus (pCaMV-GFP), medaka $\beta$-actin (pmBA-GFP) and Japanese flounder keratin (pJfKer-GFP) promoters were introduced by electroporation method. Electroporation was performed using a gene pulser (BIORAD) with voltage of $300 \mathrm{~V}$, pulse length of $0.5 \mathrm{~ms}$, pulse numbers of 4 , and pulse interval of $0.1 \mathrm{~s}$. Promoter activity was determined by analyzing GFP gene expression level using a fluorescent microscope. The results showed that CMV regulated highest number of filament callus $(34.10 \% \pm 1.49)$ expressing GFP at medium to strong fluorescence levels. CaMV promoter had relatively similar activity with CMV, but lower number of filament callus expressing GFP (10.48\% \pm 0.25$)$. mBA promoter drove GFP expression at medium level and similar number of filament callus $(8.85 \% \pm 2.31)$ expressing GFP with CaMV, while JfKer promoter had lowest activity by means in number of filament callus expressing GFP $(4.79 \% \pm 0.26)$ and GFP expression level. PCR analysis for transgenic confirmation showed a DNA band of PCR product from pCMV-GFP and pCaMV-GFP expressing filament callus in the same size (about $0.6 \mathrm{~kb}$ ) with positive control of plasmid. Thus, CMV and CaMV promoters was an appropriate promoter and foreign gene could be transferred to filament callus by electroporation method. Combining this achievement with developing a culture method of filament callus to be thallus, stable transgenic breeding in $K$. alvarezii can be feasible.
\end{abstract}

Keywords: transgenic, promoter, GFP, electroporation, filament callus, Kappaphycus alvarezii

\section{Introduction}

Kappaphycus alvarezii is one of the major sources of kappa-carrageenan for food, chemical and pharmaceutical industries (McHugh, 2003). This seaweed has been prioritized by the Ministry of

\section{"Corresponding author:}

Muh. Alias L. Rajamuddin

Postgraduated student of Bogor Agricultural University, Bogor. Polytechnic Agricultural of Pangkep, South Sulawesi. e-mail: mal_rajamuddin@ yahoo.co.id
Marine Affairs and Fisheries as one of aquaculture commodities targeted to increase on 2014. Increased production of seaweed farming can be achieved through extension and use of high quality seeds in terms of fast growth, resistant to disease and fluctuation of environmental conditions. Seaweed farming extensification program conducted by the Directorate of Aquaculture successfully increased production of seaweed. However, various problems faced in achieving the production target such as the growth rate being decrease due to disease infection and 
environmental degradation (Vairappan ,2006; Largo et al., 1997). In addition, disease and environmental factors are also affecting the quality and quantity of carrageenan (Vairappan et al., 2008). On the other hand, the increase in carrageenan consumption worldwide requires more production and high level of bioactive compound in farmed seaweed. Genetic engineering techniques have therefore been expected to improve seed stocks of seaweeds (Hallman, 2007). In fact, transgenic reasearch have been conducted on Laminaria japonica using $\beta$-glucuronidase (Li et al., 2009), Kappaphycus alvarezii using LacZ gene (Wang et al., 2010) and Gracilaria changii using LacZ gene as reporter (Huddy et al., 2012; Gan et al., 2003). In Wang et al. study, Kappaphycus alvarezii transgenic was produced by micro-particle bombardment method (Wang et al., 2010).

Application of gene transfer (transgenesis) technology in order to increase growth (Devlin et al., 1994, Nam et al., 2001; Kobayashi et al., 2007), resistant to disease (Yazawa et al., 2006; Parenrengi, 2010) and adaptation ability to the extreme environmental condition (Wang et al., 1995) have extensively been reported in various finfish and shellfish species. In seaweed, however, research is still limited to development of transgenic method and analysis of promoter activity in Laminaria japonica Aresch and Undaria pinnatifida Suringer (Qin et al., 2005).

The ability of promoter used to control the expression of foreign gene, in this study green fluorescent protein (GFP) gene was used as reporter, is one of determinant factors affecting the success of transgenesis. Various promoters have been analyzed for their activities in fish, such as cytomegalovirus / CMV (Volckaert, 1994; Arenal et al., 2008; Traxler et al., 1999), $\beta$-actin (Yoshizaki, 2001; Alimuddin et al., 2005), heat-shock protein, keratin (Gong et al., 2002 ;Yazawa et al., 2005), myosin light chains (Alimuddin, 2003) and elongation factor-1a (Yasawa et al., 2005; Alimuddin et al., 2007). Promoter activity level is determined by the match between transcription factors (cis regulators) of the promoter with trans regulators in the host (Iyengar et al., 1996; Alimuddin, 2003). Generally, promoters activity originating from the same species or family with the fish will be made transgenic are higher than those of originating from different species. In addition, number of promoter which has been isolated is still limited. Thus, it is necessary to evaluate the activity of existing promoters in order to produce seaweed transgenic.

In this study, as an initial step to produce high quality (such as high level of carrageenan content and disease resistant) seed of seaweed using transgenesis technology, four different promoters that drives GFP gene was introduced to obtain a suitable promoter for seaweed. The results of study showed that the two virus derived promoters (CMV and CaMV) and medaka $\beta$-actin promoter can regulate high foreign gene expression level in seaweed.

\section{Materials and Methods}

Source of $K$. alvarezii filament callus

$K$. alvarezii used in this study was derived from the collection of Brackishwater Aquaculture Research Center, Maros, South Sulawesi. Thalli segment, callus and filament callus were cultured in the laboratory condition according to method described by Reddy et al. (2003) and Rajamuddin (2010). Thalli segment was culture to obtain callus using solid agar medium containing growth regulators, while callus was culture in semisolid medium to produce filament callus. Filament callus were then regenerated in a liquid medium.

\section{GFP construction vectors}

Four GFP expression vectors driven by different promoters, i.e. cytomegalovirus (pCMV-GFP, Clontech), cauliflower mosaic virus (pCaMV-GFP, BIOS Cambia Labs.), Japanese medaka $\beta$-actin (pmBA-GFP, Takagi et al., 1994) and Japanese flounder 
keratin promoters (pJfKer-GFP, Yazawa et al., 2005) were examined. The first two promoters was virus origin, while the last two was from the fish.

\section{Transformation protocol}

Each GFP expression vector in concentration of $100 \mathrm{ng} / \mu \mathrm{L}$ was mixed with $K$. alvarezii callus mass as filament form. Transformation was performed by electroporation method using Gene Pulser II (Biorad, USA) in voltage of $300 \mathrm{~V}$, pulse length $0.5 \mathrm{~ms}$, pulse number 4 , and pulse interval $0.1 \mathrm{~s}$ at $2 \mathrm{~mm}$ cuvette. Those electroporation parameters were obtained from preliminary study that produced high transformation efficiency and cell viability.

\section{GFP gene expression analysis}

GFP expression was analyzed using a fluorescent microscope(Olympus BH2-RFCA) equipped with reflected light fluorescent attachment (BH2-RFC2). Observation was conducted every hour started at $1 \mathrm{~h}$ after electroporation until GFP expression level being stable. Number of cells expressing GFP and their expression level was observed after GFP was stably expressed. GFP expression levels were qualitatively classified as faint, medium and strong fluorescence.

\section{Transformant regeneration and detection}

Transformant carrying GFP was screened and regenerated by culturing the electroporated filament callus in the semisolid medium containing kanamisin 100 ppm for 1 month. Detection of transformant was conducted using fluorescent microscope and PCR method. Genomic DNA was extracted from the highest and lowest GFP expressing transformant using the Puregene DNA Isolation Kit (Gentra, USA). PCR amplification was carried out using a set primer of GFP-F (5'GGTCGAGCTGGACGG-3') and GFP-R (5' ACGAACTCCAGCAGG-3'). Amplification of GFP fragment was conducted for 35 cycles of denaturation at $94^{\circ} \mathrm{C}$ for $30 \mathrm{~s}$, annealing at $62^{\circ} \mathrm{C}$ for $30 \mathrm{~s}$, and extension at $72^{\circ} \mathrm{C}$ for 1 min. PCR product was electrophoretically separated using $1 \%$ agarose gel.

\section{Results and Discussion GFP gene expression}

The electroporation parameters used in this study was obtained in our preliminary experiment (unpublished data). As shown in Figures 1A-D, electroporated filament callus mass showed green fluorescence in some of embryos, while no GFP expression in nonelectroporated control was observed (Fig. $4 \mathrm{E})$. This indicated that GFP gene construct was successfully transferred to filament callus of seaweed. Further, percentage of filament callus expressing GFP gene was different between gene construct used (Table 1, Fig. 4). Highest percentage of filament callus expressing GFP was obtained by using CMV promoter, followed by CaMV, mBA and JfKer (Table 1). GFP gene expression levels driven by CMV, CaMV and mBA were relatively similar while JfKer was lower compared to that of the first three promoters (Fig. 4). The first two promoters is virus origin, while the last two is fish origin. Foreign gene expression levels driven by virus origin promoter were similar with $\mathrm{mBA}$ promoter of Japanese medaka fish origin, but it was lower compared to that of JfKer promoter of Japanese flounder fish origin. Furthermore, initial time to express GFP after electroporation was fastest in filament callus carrying pCMV-GFP and pCaMV-GFP constructs compared with pmBA-GFP, and the later was pJfKer-GFP. Thus, differences in the level and initial time of foreign gene to express are possibly related to difference in recognition of trans-acting protein of the host with cis-acting element of promoter (Iyengar et al., 1996; Alimuddin, 2003).

Hae is hour after electroporation. GFPexpressing cell percentage are given as means \pm S.D. Different superscript letters in GFPexpressing cell percentage indicate significant differences $(p<0.05)$ as determined by one-way ANOVA followed by Duncan's test. 
Table 1. Initial time, level of expression and percentage of cell expressing GFP in Kappaphycus alvarezii filament callus after electroporation using different gene constructs

\begin{tabular}{cccc}
\hline GFP constructs & $\begin{array}{c}\text { Initial time to } \\
\text { express GFP (hae) }\end{array}$ & $\begin{array}{c}\text { GFP expression } \\
\text { levels }\end{array}$ & $\begin{array}{c}\text { GFP-expressing cell } \\
\text { percentage }(\%)\end{array}$ \\
\hline pCMV-GFP & 1 & Mid to strong & $34.10 \pm 1.49^{\mathrm{a}}$ \\
pCaMV-GFP & 2 & Mid to strong & $10.48 \pm 0.25^{\mathrm{b}}$ \\
pmBA-GFP & 2 & Mid to strong & $8.85 \pm 2.31^{\mathrm{b}}$ \\
pJfKer-GFP & 3 & Weak & $4.79 \pm 0.26^{\mathrm{c}}$ \\
\hline
\end{tabular}
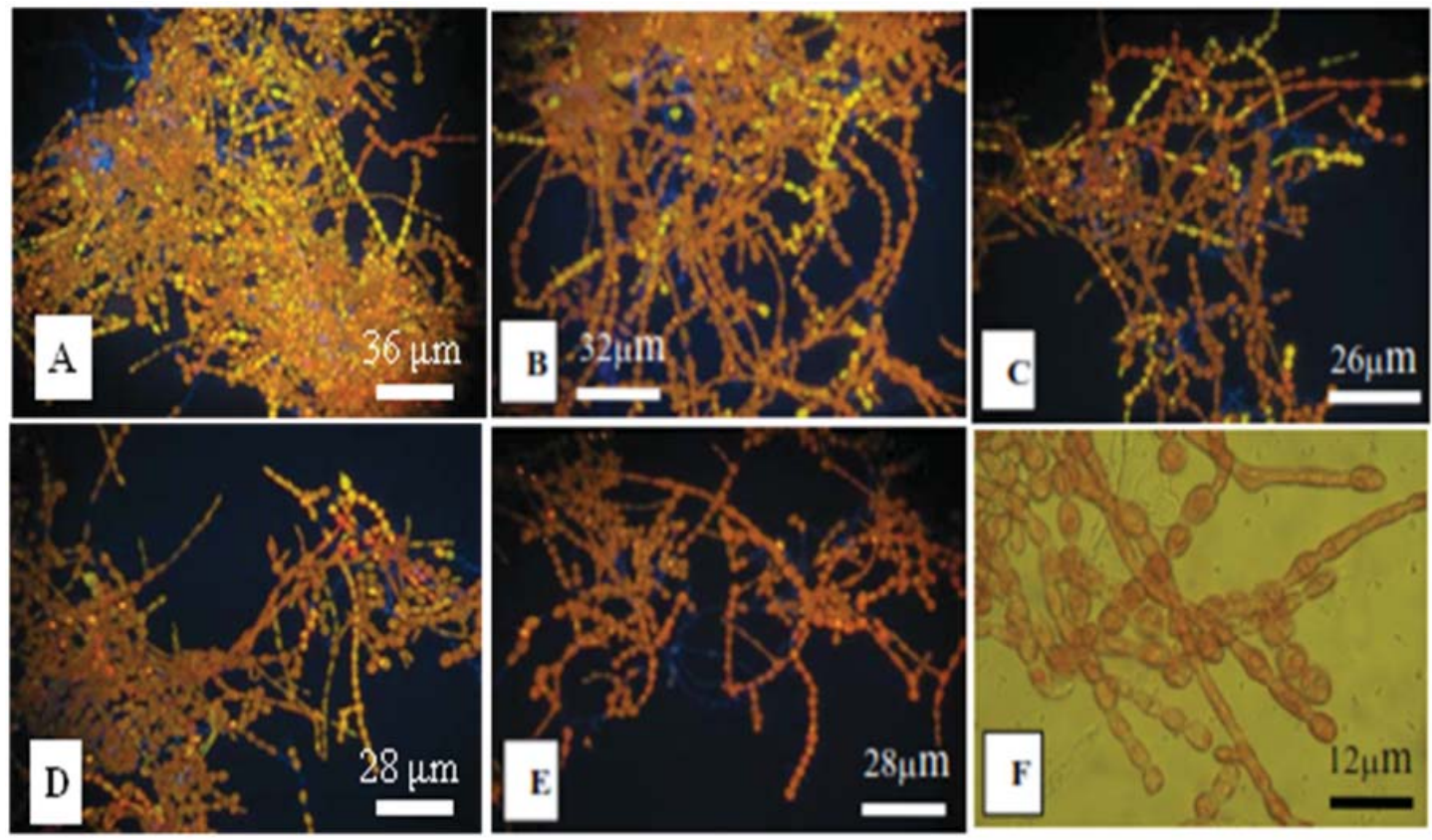

Figure 4,GFP gene expression at the electroporated filament callus of $K$. alvarezii using pCMV-GFP (A), pCaMV-GFP (B), pmBA-GFP (C), pKeratin-GFP (D) constructs, and non-electroporated control observed by fluorescent microscope (E) and by light microscope $(\mathrm{F})$.

\section{Transformant regeneration}

All gene constructs used in this study is contained kanamycin resistance gene so that the transformant can live in the medium containing kanamycin. By adding 100 ppm of kanamycin into the culture medium, the electroporated filament callus survived and grew (Fig. 5A-D), while non-electroporated control died after 1 month incubation (Fig. 5E). This indicated that the electroporated filament callus carried foreign gene construct. Furthermore, number of filament callus expressing GFP after incubation for 1 month (Fig. 5A-D) was higher compared to that of initial condition (Fig. 4), indicating the mitotic division in transgenic cells. Number of
GFP-expressing filament callus using pCMVGFP and pCaMV-GFP constructs was relatively similar and higher than that of pmBA-GFP and pJfKer-GFP. This might be correlated to initial number of cells expressing foreign gene before they regenerated. In addition, GFP-expressing cells derived from mitotic division may become a transgenic stable, though this needs a proof by Southern blot analysis.

\section{PCR analysis for transgenic confirmation}

PCR analysis was performed to reconfirm that the green fluorescence in the survived filament callus of $K$. alvarezii in the kanamycin-contained medium is from GFP 

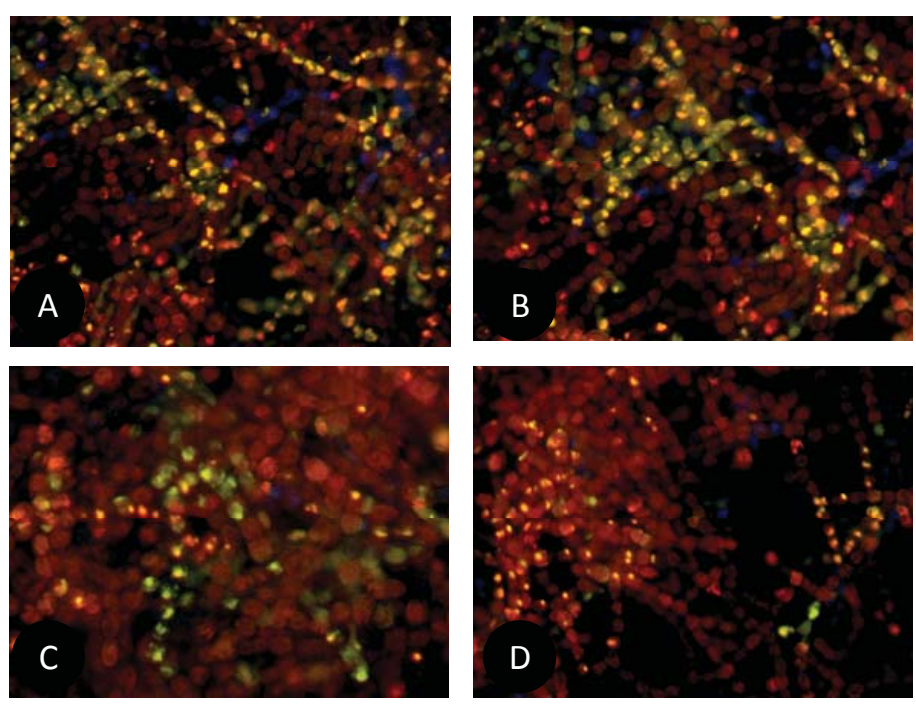

Figure 5. A constitutive GFP gene expression in filament callus of Kappaphycus alvarezii after culturing in the medium containing kanamycin 100 ppm for 1 month. (A) pCMV-GFP, (B) pCaMV-GFP, (C) pmBA -GFP, (D) pJfKer-GFP.

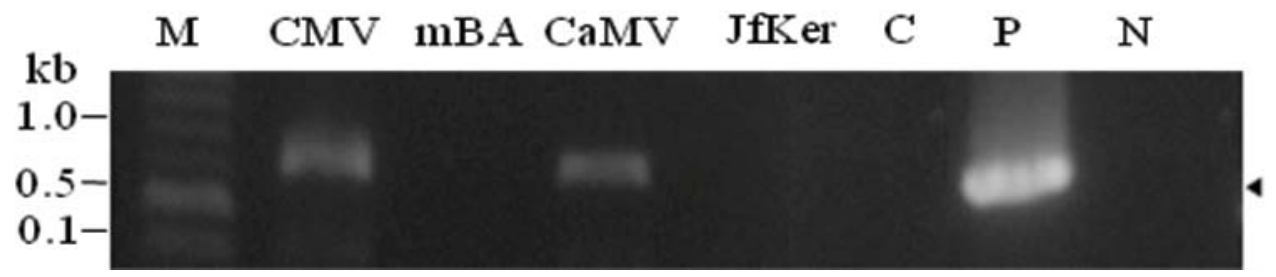

Figure 6. Result of transgene detection by PCR analysis with DNA template extracted from filament callus of Kappaphycus alvarezii Lane CMV, mBA, CaMV and JfKer are PCR product (marked by arrow head) amplified using genomic DNA from pCMV-GFP, pmBA-GFP, CaMV-GFP and pJfKer-GFP expressing filament callus, respectively; $\mathrm{C}=$ a sample product with genomic DNA from non-transgenic filament callus; lane $\mathrm{P}$ and $\mathrm{N}=$ a sample PCR product with pCMV-GFP plasmid and without DNA template, respectively. $\mathrm{M}=$ is 2-log ladder DNA marker (BioLabs, Inc., New England). The amplified fragment is about $0.6 \mathrm{~kb}$ in size.

transgene expression. As shown in Fig. 6, a DNA band of PCR product from pCMV-GFP (CMV) and pCaMV-GFP (CaMV) expressing filament callus in the same size (about 0.6 $\mathrm{kb}$ ) with the positive control of pCMV-GFP plasmid $(\mathrm{P})$ was obtained, but no PCR product in the non-electroporated control (C). This indicated that the somatic embryos showing green fluorescence were transgenic carrying pCMV-GFP and pCaMV-GFP gene constructs. PCR product from pmBA-GFP showed negative of DNA band, altough number of GFP expressing filament callus using pCaMV-GFP construct was relatively similar.

\section{Conclusion}

Electroporation method could be used to transfer GFP gene into filament callus of Kappaphycus alvarezii. Cytomegalovirus (CMV) and cauliflower mosaic virus (CaMV) promoters are more suitable for K. alvarezii in controlling GFP gene expression compared with medaka $\beta$-actin and Japanese flounder keratin promoters.

\section{Acknowledgements}

This study was supported by Center for Research and Development of Brackish Water Aquaculture (BRPBAP) Maros and Agency 
for Research Assessment and Application of Technology (BPPT) Serpong. The pmBA-GFP and pJfKer-GFP constructs were kindly gift of Prof. Dr. Goro Yoshizaki and Prof. Dr. Takashi Aoki, respectively.

\section{References}

Alimuddin, Yoshizaki G, Carman O, Takeuchi T. 2007. Efektivitas promoter hCMV, mEF1? dan mAct dalam mengatur ekspresi gen asing pada transgenik ikan zebra. Jurnal Akuakultur Indonesia, 6:65-77.

Alimuddin, Yoshizaki G, Kiron V, Satoh S, Takeuci T. 2005. Enhancement of EPA and DHA biosynthesis by over-expression of Masu Salmon $\Delta 6$ Desaturase-Like gene in Zebrafish. Transgenic Res 14:159-165.

Alimuddin. 2003. Introduction and expression of foreign $\Delta 6$-desaturase-like gene in a teleostean fish. Thesis in Graduate School of Aquatic Biosciences, Tokyo University of Fisheries. Japan.

Arenal A, Pimentel R, Guimarais M, Rodriguez A, Martinez R, Abad Z. 2000. Gene transfer in shrimp (Litopenaeus schimitti) by electroporation of singlecell embryos and injection of naked DNA into adult muscle. Biotechnol Appl 17:247-250.

Devlin RH, Sundstrom LF, Muir MW. 2006. Interface of biotechnology and ecology for environmental risk assessments of transgenic fish. Trend Biotechnol 24:8997.

Gan SY, Qin S, Othman RY, Yu D, Phang SM. 2003. Transient expression of lacZ in particle bombarded Gracilaria changii (Gracilariales, Rhodophyta). Journal of Applied Phycology. 5: 351-353.

Gong Z, Ju B, Wang X, He J, Wan H, Sudha PM, Yan T. 2002. Green fluorescent protein expression in germ line transmitted transgenic zebrafish under a stratified ephitelial promoter from keratin8. Developmental Dynamics 223:204-215.
Hallmann A. 2007. Algal transgenics and biotechnology. Trans Plant J. 1(1) : 8189.

Huddy SM, Meyers AE, Coyne VE. 2012. Transformation of lacZ using different promoters in the commercially important red alga, Gracilaria gracilis. African J of Biotech. 11(8) :1879-1885.

Iyengar A, Muller F, Maclean N. 1996. Regulation and expression of transgenes in fish-a review. Transgenic Research 5: 147-166.

Kobayashi SI, Alimuddin, Morita T, Miwa M, Lu J, Endo M, Takeuchi T, Yoshizaki G. 2007. Transgenic Nile tilapia (Oreochromis niloticus) overexpressing growth hormone showed reduced ammonia excretion. Aquaculture 270:427435.

Largo DB, Fukami K, Adachi M, Nishijima T. 1997. Direct enumeration of total bacteria from macroalgae by epifluorescence microscopy asapplied to the fleshy red algae Kappaphycus alvarezii and Gracilaria spp. (Rhodophyta). J Phycol 33:554-557.

Li F, Qin S, Jiang P, Wu Y, Zhang W. 2009. The integrative expression of GUS gene driven by FCP promoter in the seaweed Laminaria japonica (Phaeophyta). J Appl Phycol. 21:287-293.

McHugh DJ. 2003. A Guide to the Seaweed Industry. FAO Fisheries Technical Paper, No. 441. FAO, Rome. 105p.

Nam YK, Noh JK, Cho YS, Cho HJ, Cho KN, Kim CG, Kim DS. 2001. Dramatically accelerated growth and extraordinary gigantism of transgenic mud loach Misgurnus mizolepis. Transgenic Res 10:353-362.

Qin S, Jiang P, Tseng C. 2005. Transforming kelp into a marine bioreactor. Trends Biotehcnol. 23 (5): 264-268. doi:10.1016/j. tibtech.2005.03.010.

Rajamuddin MAL, Jaya AA, Ridwan, Suryati E. 2010. Kajian induksi kalus rumput laut Kappaphycus alvarezii 
Rajamuddin et al.

untuk produksi embrio somatik. J. Ris. Akuakultur 5(2):.211-219.

Reddy CRK, Kumar GRK, Siddhanta AK, Tewari A. 2003. In vitro somatic embryogenesis and regeneration of somatic embryos from pigmented callus of Kappaphycus alvarezii (Doty) Doty (Rhodophyta, Gigartinales). J Phycol 39: 610-616.

Takagi S, Sasado G, Tamiya G, Ozato K, Wakamatsu Y, Takeshita A, Kimura M. 1994. An efficient expression vector for transgenic medaka construction. $\mathrm{Mol}$ Mar Biol Biotecnol 3:192-199

Traxler GS, Anderson E, LaPatra SE, Richard J, Shewmaker B, Kurath G. 1999. Naked DNA vaccination of Atlantic salmon Salmo salar against IHNV. Dis Aquat Organ 38:183-190.

Vairappan CS, Chung CS, Hurtado AQ, Soya FE, Bleicher-Lhonneur G, and Critchley A. 2008. Distribution and symptoms of epiphyte infection in major carrageenophyte-producing farms. J Appl Phycol 20:477-483.

Vairappan CS. 2006. Seasonal occurrences of epiphytic algae on the commercially cultivated red alga Kappaphycus alvarezii (Solieriaceae, Gigartinales, Rhodophyta). J Appl Phycol 18:611617.

Volckaert FA, Hellemans BA, Galbusera P, Ollevier F. 1994. Replication, expression and fate of foreign DNA during embryonic and larval development of the African Catfish Clarias gariepinus. Molecular Marine Biology and Biotechnology 3(2):57-69.

Wang J, Jiang P, Cui Y, Deng X, Li F, Liu J, Qin S. 2010. Genetic transformation in Kappaphycus alvarezii using microparticle bombardment: a potential strategy for germplasm improvement. Aquacult Int. 18:1027-1034. doi:10.1007/ s10499-010-9320-0.

Wang R, Zhang P, Gong Z, Hew CL. 1995. Expression of the antifreeze protein gen in transgenic goldfish (Carassius
I.J. Biotech.

auratus) and its implication in cold adaptation [abstract]. Mol Mar Biol Biotechnol 4:20-26.

Yazawa R, Hirono I, Aoki T. 2005. Characterization of promoter activities of four different Japanese flounder promoters in transgenic zebrafish. Mar Biotechnol 7:625-633.

Yoshizaki G. 2001. Gene transfer in salmonidae: applications to aquaculture. Suisanzoshoku 49:137-142. 